\title{
MEAT FATTY ACID PROFILE OF PIGS FED LINSEED ENRICHED DIET
}

\author{
Đ. Okanović, D. Ivanov, D. Palić, A. Mandić, N. Ilić \\ University of Novi Sad, Institute of Food Technology, Bulevar Cara Lazara 1 \\ 21000 Novi Sad, Serbia \\ Corresponding author: djordje.okanovic@fins.uns.ac.rs \\ Original scientific paper
}

\begin{abstract}
The aim of this study was to evaluate the influence of diet supplemented with linseed rich additive on fatty acid profile and omega-fatty acids content in pig meat. Twelve pigs were divided in a control and experimental group and grown to $110 \mathrm{~kg}$ of live weight. The experimental group was fed a standard diet enriched with $2.5 \%$ of commercial additive Vitalan ${ }^{\circledR}$. After the end of feeding period, the meat samples from both groups were analyzed for fatty acids content in raw and roasted meat. The ratio between omega- 6 and omega- 3 acids was established. Samples from experimental group fed with linseed enriched diet showed higher $\omega-3$ acids content in meat $(6.24 \%-7.23 \%)$, compared to the control group $(0.71 \%-1.64 \%)$, thus making it better for a human consumption from a health perspective. Linseed enriched diet positively influenced fatty acid composition of pig M. Longissimus dorsi muscle by decreasing SFA content, as well as increasing PUFA and UFA content. Heat treatment did not significantly decreased content of stearic and linoleic fatty acids in any sample. It was concluded that the diet enriched with extruded linseed had beneficial effect on the majority of monitored parameters in the study.
\end{abstract}

Key words: $n-3$ polyunsaturated fatty acids, linseed, pig meat

\section{Introduction}

Many clinical, epidemiological and biological studies suggest that dietary fats play an important role in human health and well being (Gebauer et al., 2006). Results from those studies ascribe a particular significance to $n-3$ polyunsaturated fatty acids (PUFA). This class of fatty acids are found to have anti-inflammatory, antithrombogenic, and hypotriglyceridemic properties, they are also active against some types of cancer like colon, breast and prostate cancer (Connor, 2000). n-3 PUFA consumption also reduces risk of cardiovascular disease. At the same time increased levels of n-6 fatty acids are associated with an increase in chronic diseases (Givens et al., 2006). 
In paper, Sretenović et al., (2009), the significance of omega-3 fatty acids in human nutrition is presented. As essential substances they cannot be synthesized in the organism, but have to be introduced through diet. Also, the significance of some essential omega- 6 fatty acids as well as their mutual relation, are presented. The role of omega-3 fatty acids in animal nutrition is also pointed out in this paper, introduced or consumed by animals either by grazing or as diet supplement, which influence improvement of their production, reproduction and health performances. The main reason for this is production of animal feed from grains rich in n- 6 fatty acids which subsequently leads to meat rich in the same type of fatty acids (Crawford, 1968). Being aware of n-3 PUFA benefits and health promoting effects, the nutritionists recommend a diet rich in n-3 fatty acids as well as a lower n-6/n-3 ratio from the current 15-20:1 to 1-4:1 (Simopoulos, 2002). Since animals are not able to synthesize n-3 and n-6 fatty acids and animal diet determines the fatty acid composition in meat, change in fatty acids ratio and composition in meat can be achieved through the change in animal diet (Mourot and Hermier, 2001; Ivanov et al., 2009). Most common way to perform this is by enriching the animal feed with fish oil/fish meals or with plant oils rich in n-3 PUFA or seed meals such as linseed (Raes et al., 2004; Kouba et al., 2003; Stevanović et al., 2011). Monogastric animals (like pigs) are better target for this approach because the dietary fatty acids are absorbed from the intestine unchanged. In this way, composition of fatty acids in meat could be modified by dietary means ultimately improving nutritional and health value of the meat (Enser et al., 2000).

The objective of this study was to investigate the influence of linseed enriched diet (rich in n-3 PUFA) on fatty acid composition in raw and roasted pig meat. The overall aim of the study was to improve the nutritional value of pig meat using linseed enriched diet, thus making it a good source of beneficial n-3 fatty acids.

\section{Materials and Methods}

\section{Animals and diet}

Total twelve pigs, Pietrain $\mathrm{x}$ (Landrace $\mathrm{x}$ Great Yorkshire) were used in the study, which has been conducted at the pig farm „Sabo Janos”, Jermenovci, Serbia. Twelve pigs were divided into two groups and fed with two types of diet, a standard diet and diet enriched with $2.5 \%$ of Vitalan ${ }^{\circledR}$ (Vitalac, France), until reaching approximate $110 \mathrm{~kg}$ of live weight, when they were slaughtered. Vitalan ${ }^{\circledR}$ contains $85 \%$ extruded linseed, which made the diet rich in omega-3 acids and the rest were wheat bran and antioxidants. The composition of the diets is shown in Table 1. 
Table 1. Composition of diets for pigs

\begin{tabular}{|l|c|c|}
\hline Components (\%) & Control group & Experimental group \\
\hline Vitalan ${ }^{\circledR}$ & & 2.5 \\
\hline Maize & 51.0 & 50.0 \\
\hline Barley & 28.0 & 26.8 \\
\hline Soybean meal & 18.0 & 17.7 \\
\hline Premix & 2.5 & 2.5 \\
\hline Acidifier & 0.5 & 0.5 \\
\hline Total & $\mathbf{1 0 0 . 0}$ & $\mathbf{1 0 0 . 0}$ \\
\hline
\end{tabular}

\section{Slaughtering and sampling}

The animals were slaughtered and samples of pig meat (M. Longissimus dorsi, bacon and back fat), $200 \mathrm{~g}$ each, from both groups were collected and kept in the refrigerator at $4^{0} \mathrm{C}$ until further use. A half of the samples were roasted in the oven at the temperature of $80-85^{\circ} \mathrm{C}$ until the temperature in the centre of the meat reached $69^{\circ} \mathrm{C}$ (about 1 hour).

After 24 hours, the samples were sent to the laboratories of Food Technology Institute in Novi Sad, where fatty acid analysis and sensory evaluation were performed.

\section{Fat extraction for fatty acid analysis}

Supercritical fluid extraction with $\mathrm{CO}_{2}$ was used for preparation of fat extracts, as recommended for fatty acid analysis (Ivanov et al., 2011). Extractions were performed on a LECO TFA2000 fat analyzer with methods developed in the laboratory. Temperature, pressure and extraction flow rates were adopted from existing LECO procedures (LECO Corporation, 2003). Cell temperature and flow path temperatures were set at $100{ }^{\circ} \mathrm{C}$. The collection vials on the instrument are not temperature-controlled and remained near room temperature, approximately $30^{\circ} \mathrm{C}$. Operating pressure was 9000 psi. Extraction flow rate was set at $1.31 \mathrm{~min}$. Infusorial soil (LECO Corporation, 2003) was used to disperse the sample and when used, modifier was added to the mix prior to transferring the sample to the extraction thimble. From the extracted lipids, fatty acid methyl esters were prepared with method that use boron trifluoride/methanol solution (Veresbaranji, 1996). Nitrogen gas was used for drying and removing solvents from fatty acid methyl esters. Obtained samples were analyzed by a GC Agilent 7890A system with FID, auto-injection module for liquid and headspace sampling, equipped with fused silica capillary column (DB-WAX $30 \mathrm{~m}, 0.25 \mathrm{~mm}, 0.50 \mu \mathrm{m}$ ). Helium was used as a carrier gas (purity $>99.9997$ vol. $\%$, flow rate $=1.26 \mathrm{ml} / \mathrm{min}$ ). The fatty acids peaks were identified by comparison of retention times with retention times of standards from Supelco 37 component fatty acid methyl ester mix and with data 
from internal data library, based on previous experiments. Results were expressed as mass of fatty acid or fatty acid group (g) per $100 \mathrm{~g}$ of fatty acids, and as a ratio between omega- 6 and omega- 3 fatty acids.

\section{Statistical analysis}

STATISTICA software version 9 (Statsoft, Tulsa, OK, USA) was used for analyzing variations (analysis of variance - ANOVA) and for Tukey's HSD comparison of means of samples (Statistica, 2006).

\section{Results and Discussion}

Fatty acid composition of the meat ( $M$. longissimus dorsi), heat treated meat, fat and bacon of pigs fed with standard and linseed enriched diet is shown in Table 2.

The major fatty acids in all tissues (listed from most prevalent to least) were oleic (C18:1), linoleic and other isomers of $\mathrm{C} 18: 2$, palmitic (C16:0), palmitoleic (C16:1) and stearic (C18:0). These five fatty acids accounted for over $90 \%$ of the total fatty acids in the pig tissues.

The data showed that fatty acid compositions of the examined samples were broadly similar. However, there were important species differences. As it is known from the literature, pigs have relatively high proportion of linoleic acid (C18:2 n-6), major PUFA, which is entirely derived from the diet (Wood et al., 2008). The column used for gas chromatographic determination did not have possibility to separate positional isomers, in combination with used standard mixture, but it could be noticed that all experimental samples (in pigs fed the experimental diet) have had higher content of total C18:2 fatty acid, to use of linseed enriched diet.

From the results shown in Table 2 for fresh and roasted pig meat, bacon and back fat, it is evident that use of linseed enriched diet resulted in increased levels of omega-3 fatty acids in the experimental group $(6.24 \%-7.23 \%)$ compared to the control group $(0.71 \%-1.64 \%)$. This significantly contributed to the more favourable ratio of omega-6/omega-3 in the experimental group (3.35-3.91) compared to the control group (11.96-31.49).

Results for the content of free fat in both examined groups have shown that the proportion of free fat in the control and experimental groups were similar. Meat is the major source of fat including SFA in the human diet. SFA have been generally labeled as the cause of cancers and coronary heart disease. 
Table 2: Fatty acid composition (\%) of different pig tissues

\begin{tabular}{|c|c|c|c|c|c|c|c|c|}
\hline & \multicolumn{2}{|c|}{ Meat } & \multicolumn{2}{|c|}{ Roasted meat } & \multicolumn{2}{|c|}{ Back fat } & \multicolumn{2}{|c|}{ Bacon } \\
\hline Sample & $\mathrm{C}$ & $\mathbf{E}$ & $\mathrm{C}$ & $\mathbf{E}$ & $\mathrm{C}$ & $\mathbf{E}$ & $\mathrm{C}$ & $\mathbf{E}$ \\
\hline Free fat (\%) & 5.11 & 5.57 & 6.02 & 5.34 & 86.50 & 82.90 & 28.10 & 26.10 \\
\hline Fatty acid & & & Fatty a & content & 6 of total & tty acid) & & \\
\hline C10:0 & 0.08 & 0.05 & 0.09 & 0.07 & 0.06 & 0.06 & 0.09 & 0.07 \\
\hline SD & 0.02 & 0.06 & 0.07 & 0.05 & 0.03 & 0.05 & 0.06 & 0.03 \\
\hline C12:0 & 0.04 & 0.03 & 0.04 & 0.04 & 0.04 & 0.04 & 0.04 & 0.04 \\
\hline SD & 0.01 & 0.02 & 0.02 & 0.03 & 0.03 & 0.02 & 0.01 & 0.03 \\
\hline C14:0 & 0.75 & 0.57 & 0.75 & 0.63 & 0.72 & 0.72 & 0.77 & 0.67 \\
\hline SD & 0.24 & 0.26 & 0.34 & 0.09 & 0.36 & 0.29 & 0.31 & 0.19 \\
\hline C16:0 & 8.98 & 6.90 & 9.09 & 7.31 & 9.00 & 8.99 & 8.89 & 7.79 \\
\hline SD & 0.89 & 0.71 & 1.21 & 0.96 & 1.01 & 0.24 & 0.35 & 0.41 \\
\hline C16:1 & 9.25 & 8.08 & 9.47 & 8.99 & 7.08 & 6.04 & 9.01 & 8.77 \\
\hline SD & 0.67 & 0.58 & 0.91 & 0.87 & 0.61 & 0.89 & 1.03 & 0.99 \\
\hline C17:0 & 0.47 & 0.71 & 0.41 & 0.72 & 0.64 & 0.64 & 0.43 & 0.71 \\
\hline SD & 0.23 & 0.09 & 0.16 & 0.65 & 0.13 & 0.21 & 0.13 & 0.51 \\
\hline C17:1 & 0.42 & 0.66 & 0.36 & 0.69 & 0.42 & 0.42 & 0.41 & 0.64 \\
\hline SD & 0.16 & 0.51 & 0.24 & 0.29 & 0.31 & 0.14 & 0.52 & 0.16 \\
\hline C18:0 & $6.83 *$ & $4.94 *$ & $7.33^{*}$ & $4.85 *$ & 7.33 & 7.13 & 6.62 & 5.31 \\
\hline SD & 0.87 & 0.68 & 0.19 & 0.34 & 0.16 & 0.65 & 0.94 & 0.36 \\
\hline C18:1 $c+t$ & $48.91^{* *}$ & 42.49 ** & $50.61^{*}$ & $44.38^{*}$ & 48.15 & 48.71 & $50.59 * *$ & $41.11 * *$ \\
\hline SD & 1.06 & 0.98 & 1.03 & 1.01 & 0.89 & 0.88 & 0.97 & 0.79 \\
\hline C18:2 & $19.61^{* *}$ & $24.22 * *$ & $19.96^{* *}$ & $24.53 * *$ & $22.36^{* *}$ & $27.20^{* *}$ & $20.07 * *$ & $26.11 * *$ \\
\hline SD & 0.97 & 0.89 & 0.76 & 1.02 & 0.96 & 0.87 & 0.96 & 1.01 \\
\hline C18:3n3 & $1.64 * *$ & $7.23^{* *}$ & $0.69^{* *}$ & $6.24^{* *}$ & $0.71 * *$ & $7.20 * *$ & $0.79 * *$ & $6.67^{* *}$ \\
\hline SD & 0.62 & 0.89 & 0.46 & 0.79 & 0.51 & 0.96 & 0.49 & 0.69 \\
\hline C20:0 & 0.13 & 0.10 & 0.12 & ND & 0.16 & 0.14 & 0.13 & 0.10 \\
\hline SD & 0.06 & 0.09 & 0.11 & - & 0.14 & 0.08 & 0.05 & 0.09 \\
\hline C20:1 & 1.05 & 0.93 & $1.04 *$ & $0.47 *$ & 1.45 & 1.44 & $1.13^{*}$ & $0.70^{*}$ \\
\hline SD & 0.25 & 0.21 & 0.34 & 0.12 & 0.64 & 0.61 & 0.56 & 0.23 \\
\hline C20:2 & $0.65^{*}$ & $1.01 *$ & 0.60 & 0.77 & 0.88 & 0.88 & 0.73 & 0.79 \\
\hline SD & 0.22 & 0.52 & 0.14 & 0.31 & 0.19 & 0.17 & 0.11 & 0.25 \\
\hline C20:4 & 0.33 & 0.32 & 0.30 & ND & ND & ND & ND & ND \\
\hline SD & 0.15 & 0.14 & 0.10 & - & - & - & - & - \\
\hline C20:3 n3+n6 & 0.85 & 3.66 & ND & 0.97 & ND & ND & ND & ND \\
\hline SD & 0.21 & 0.41 & - & 0.12 & - & - & - & - \\
\hline C18:2 / C18:3n3 & 11.96 & 3.35 & 28.93 & 3.93 & 31.49 & 3.78 & 25.41 & 3.91 \\
\hline SFA & 17.28 & 13.30 & 17.83 & 13.61 & 17.95 & 17.73 & 16.98 & 14.69 \\
\hline MUFA & 59.63 & 52.17 & 61.49 & 54.53 & 57.10 & 56.61 & 61.14 & 51.23 \\
\hline PUFA & 23.09 & 36.44 & 20.86 & 32.52 & 23.95 & 35.28 & 21.59 & 33.57 \\
\hline UFA & 82.72 & 88.60 & 82.35 & 87.05 & 81.05 & 91.89 & 82.73 & 84.79 \\
\hline MUFA/SFA & 3.45 & 3.92 & 3.45 & 4.01 & 3.18 & 3.19 & 3.60 & 3.49 \\
\hline PUFA/SFA & 1.34 & 2.74 & 1.17 & 2.39 & 1.33 & 1.99 & 1.27 & 2.29 \\
\hline
\end{tabular}

- control; E - experimental; SD - standard deviation ND - not determined; SFA - saturated fatty acid; MUFA - monounsaturated fatty acid; PUFA - polyunsaturated fatty acid; UFA - total unsaturated fatty acid,

*-statistically significant difference between the experimental and control samples of the same group within the row, at $\mathrm{p}<0.05$

**-statistically significant difference between the experimental and control samples of the same group within the row, at $\mathrm{p}<0.01$ 
The average ratio of PUFA/SFA recommended by the British Department of Health is more than 0.45 , and $\mathrm{WHO} / \mathrm{FAO}$ experts have reported guidelines for a "balanced diet" in which suggested ratio of PUFA/SFA should be above 0.4 (Wood et al., 2003; HMSO. 1994). In our study, that ratio was significantly higher ( $\mathrm{p}<$ 0.05 ) than recommended values in all samples (from 1.17 to 2.74). Scollan et al. (2006), reported that high values of PUFA/SFA ratios in pig $M$ longissimus dorsi are consequence of high level of linoleic acid (C18:2 n-6). In our study, after heat treatment of $M$. longissimus dorsi muscle, there was no significant $(\mathrm{p}>0.05)$ decrease of PUFA/SFA ratio, but between results in pig muscles fed with linseed enriched diet, there was a significant increase $(p=0.02)$ of PUFA/SFA ratio, in comparison with control samples.

$\Delta 5$ and $\Delta 6$ desaturase and elongase enzymes have an important role to synthesize long chain (C20-22) PUFA from 18:2n-6 and 18:3n-3. Muscles contained very high proportion of these long chain fatty acids, unlike fat and bacon, where $\mathrm{C} 20: 4$ and $\mathrm{C} 20: 3 n 3+n 6$ were not even detected. Although these fatty acids show positive nutritional effect, recommendation is that their ratio in tissue should not be more than 4.0 (Wood et al., 2003; Scollan et al., 2006), which have been the case in all our samples, except for the samples E (Table 2).

Comparison of fatty acid content in M. longissimus dorsi muscle before and after heat treatment showed that there was no significant change $(p>0.05)$ in fatty acid composition between these samples (Fig. 1).

On the other hand, samples of M. longissimus dorsi of the control and experimental groups showed significant differences in fatty acid composition (Fig. $2)$. SFA content decreased significantly $(\mathrm{p}=0.006)$, MUFA content also significantly $(\mathrm{p}=0.04)$ decreased, and PUFA and UFA contents significantly $(\mathrm{p}=$ 0.03 and $\mathrm{p}=0.02$, respectively) increased in experimental groups.

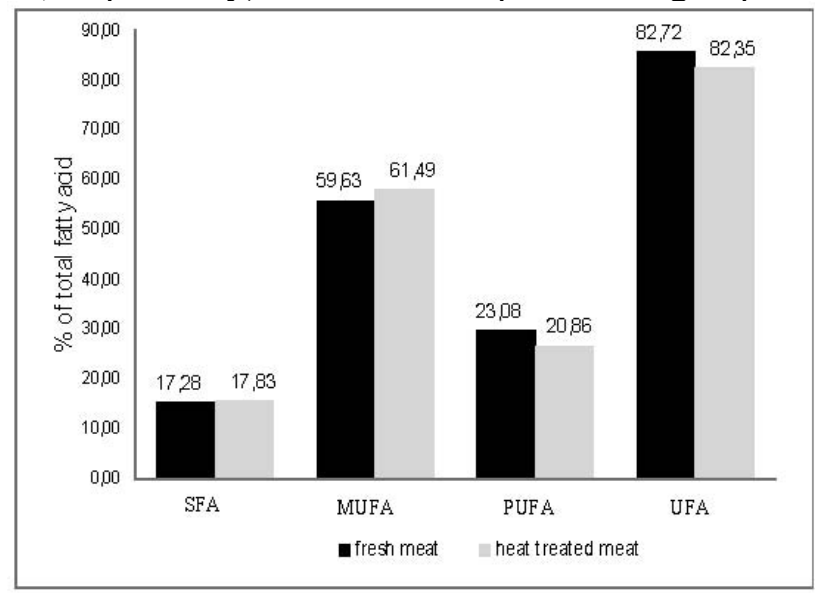

SFA - saturated fatty acid, MUFA - monounsaturated fatty acid, PUFA - polyunsaturated fatty acid; UFA - total unsaturated fatty acid

Figure 1. Changes of fatty acid composition after heat treatment in $M$. longissimus dorsi muscle of pigs fed with control and linseed enriched diet 


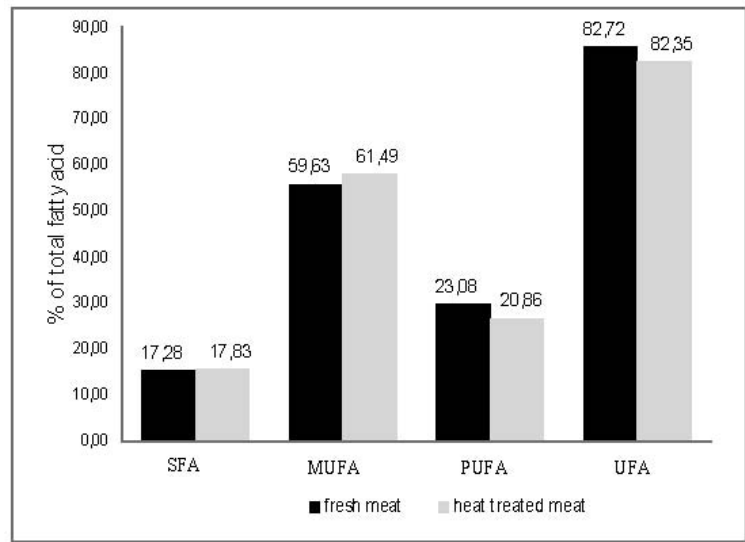

SFA - saturated fatty acid, MUFA - monounsaturated fatty acid; PUFA - polyunsaturated fatty acid, UFA - total unsaturated fatty acid; Levels of significance: ${ }^{*} \mathrm{p}<0.05$ for results of the same group; $* * \mathrm{p}<0.01$ for results of the same group

Figure 2. Fatty acid composition in M. Longissimus dorsi muscle of pigs fed with control and linseed enriched diet

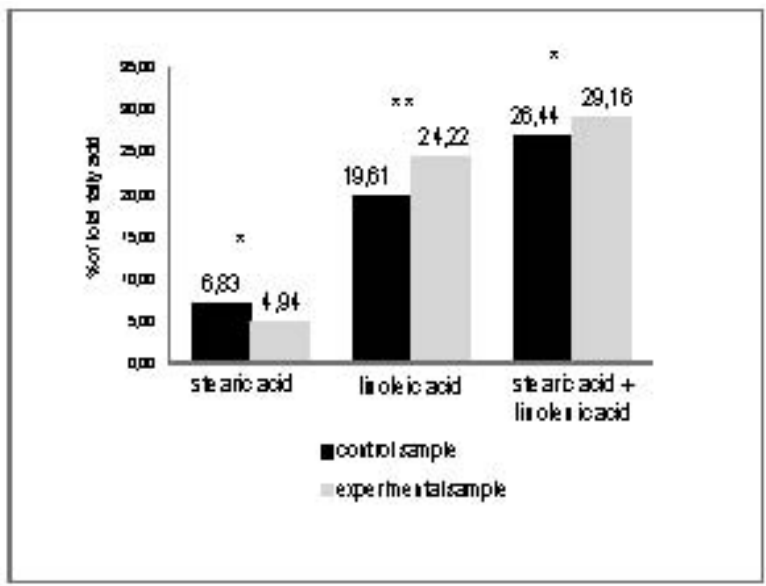

Levels of significance: ${ }^{*} \mathrm{p}<0.05$ for results of the same group; ${ }^{* *} \mathrm{p}<0.01$ for results of the same group

Figure 3. Content of the stearic and linoleic acid in $M$. longissimus dorsi of pigs fed control and linseed enriched diet

It is known that UFA containing double bonds are easily oxidized, and thus fatty acid composition can influence the palatability of meat, as well as that the effect of fatty acids on meat tenderness is due to the different melting points of individual fatty acids, especially stearic and linoleic acid (Jeong et al., 2010). 
In Figure 3 are shown changes in the content of these two acids and their total amounts in M. longissimus dorsi, as a result of the differences in composition of standard (control) and linseed enriched diet used for feeding of pigs.

As it can be seen from the Fig. 3, linseed enriched diet significantly influenced the content of both stearic and linoleic acid $(p=0.013$ and $p=0.003$, respectively). Although the stearic acid content decreased, the content of linoleic acid increased to a level that the sum of these two acids was significantly higher in comparison with the meat of pigs fed the control diet. After the heat treatment, the content of those fatty acids were lower, in both, control and experimental samples, but the differences were insignificant $(\mathrm{p}>0.05)$. Linseed enriched diet positively influenced the content of stearic and linoleic acid, and therefore it might positively affected the tenderness of $M$. longissimus dorsi muscle. Heat treatment did not significantly decrease the content of these fatty acids in any sample, and consequently, probably do not showed significant interference with the tenderness of pig meat (Okanović et al., 2010).

\section{Conclusions}

Based on the results of this study, the following conclusions can be made:

- Levels of omega-3 fatty acids in the fresh and roasted meat of M. longissimus dorsi, bacon and back fat in experimental group were much higher than in the control group, which made the ratio of omega- 6 to omega- 3 fatty acids much more favourable toward n-3 fatty acids in the experimental group.

- From nutritional point of wiev, our study justified the use of the extruded linseed enriched diet to improve the ratio of omega- 6 and omega- 3 fatty acids to the desired level less than 4 .

- Linseed enriched diet positively influenced the fatty acid composition of pig $M$. longissimus dorsi muscle by decreasing SFA content, while increasing PUFA and UFA contents.

- Heat treatment did not significantly decreased content of stearic and linoleic fatty acids in any sample.

Our studies could contribute to improvement of the nutritional value of pig meat by use of linseed enriched diet, thus making it a good source of beneficial n-3 fatty acids.

\section{Acknowledgement}

The experimental work represented in this paper is a part of Integrated and Interdisciplinary Research Project funded by Serbian Ministry of Education, Science and Technological Development, Project No: III 46012.

\section{Masnokiselinski profil mesa svinja hranjenih smešom obogaćenom semenom lana}

Đ. Okanović, D. Ivanov, D. Palić, A. Mandić, N. Ilić 


\section{Rezime}

Cilj istraživanja bio je da se utvrdi uticaj smeše sa dodatkom aditiva bogatog lanenim semenom na masnokiselinski profil i sadržaj omega-masnih kiselina u svinjskom mesu.

Dvanaest grla podeljeno je u dve grupe: kontrolnu i eksperimentalnu, i uzgajano do težine od 110 kilograma. Eksperimentalna grupa je hranjena standardnom smešom obogaćenom sa $2.5 \%$ komercijalnog aditiva Vitalan ${ }^{\circledR}$. Na kraju perioda uzgoja analiziran je sadržaj masnih kiselina svežeg i pečenog mesa uzoraka uzetih iz obe grupe. Takođe je utvrđen odnos između omega-6 i omega-3 masnih kiselina.

Uzorci iz eksperimentalne grupe hranjene smešom obogaćenom lanom pokazali su viši sadržaj omega-3 masnih kiselina u mesu, čineći ih poželjnijim sa stanovišta ljudske ishrane i zdravlja. Ishrana obogaćena lanom pozitivno je uticala na sastav masnih kiselina u mišiću $M$. Longissimus dorsi snižavajući sadržaj zasićenih masnih kiselina i povećavajući sadržaj mono- i polinezasićenih masnih kiselina. Toplotni tetman nije značajno uticao na sadržaj stearinske i linolne kiseline ni $\mathrm{u}$ jednom uzorku. Na kraju je zaključeno da ishrana obogaćena ekstrudiranim lanenim semenom ima blagotvoran uticaj na većinu parametara koji su praćeni tokom eksperimenta.

\section{References}

CONNOR W.E. (2000): Importance of $n$-fatty acids in health and disease. American Journal of Clinical Nutrition, 71, 171S-175S.

CRAWFORD M.A. (1968): Fatty acid ratios in free-living and domestic animals. Lancet I, 1329-1333.

ENSER, M., RICHARDSON, R.I., WOOD, J.D., GILL, B.P. \& SHEARD, P.R. (2000): Feeding linseed to increase the the n-3 PUFA of pork: fatty acid composition of muscle, adipose tissue, liver and sausages. Meat Science, 55, 201-212.

GEBAUER S.K., PSOTA T.L., HARRIS W.S., KRIS-ETHERTON P.M. (2006): n-3 Fatty acid dietary recommendations and food sources to achieve essentiality and cardiovascular benefits. American Journal of Clinical Nutrition .83(suppl). $1526 \mathrm{~S}-1535 \mathrm{~S}$

GIVENS, D.I., KLIEM, K.E., GIBBS, R.A. (2006): The role of meat as a source of n-3 polyunsaturated fatty acids in the human diet. Meat Science, 74, 209-218.

HMSO. UK DEPARTMENT OF HEALTH (1994): Nutritional aspects of cardiovascular disease. London. Report on Health and Social subject. 46. 37 - 46.

IVANOV, D., ČOLOVIĆ, R., BERA, O., LEVIĆ, J., SREDANOVIĆ, S., (2011): Supercritical fluid extraction as a method for fat content determination and preparative technique for fatty acid analysis in mesh feed for pigs. Eur. Food Res. Technol. 233 (2), 343-350

IVANOV, D., LEVIĆ, J., SREDANOVIĆ, S., (2009): Fatty acid composition of various soybean products, Food and Feed Research, 38 (2), 65-70. 
JEONG, D.W., CHOI, Y.M., LEE, S.H., CHOE, J.H., HONG, K.C., PARK, H.C., KIM, B.C. (2010): Correlations of trained panel sensory values of cooked pork with fatty acid composition, muscle fiber, and pork quality characteristics in Berkshire pigs. Meat Science, 86, $607-615$.

KOUBA, M., ENSER, M., WHITTINGTON, F.M., NUTE, G.R. \& WOOD, J.D. (2003): Effect of a high-linolenic acid diet on lipogenic enzyme activities, fatty acid composition and meat quality in the growing pig. Journal of Animal Science, 81, 1967-1979.

LECO Corporation (2003): Organic application note, St. Joseph, MI http://www.leco.com/resources/application notes/pdf/TFE2000 MEATS_CRUDE

FAT AOAC PVM 3-2000 203-821-122.pdf

MOUR̄OT, J. \& HERMIER, D. (2001): Lipids in monogastric animals meat. Reproduction Nutrition Development, 41, 109-118.

OKANOVIĆ, Đ., PALIĆ, D., ILIĆ, N., 2010. Influence of addition of linseed on the diet on meat quality of piglets. Quality of Life 1 (2-4), 134-138

RAES, K., DE SMET, S. \& DEMEYER, D. (2004): Effect of dietary fatty acids on incorporation of long chain polyunsaturated fatty acids and conjugated linoleic acid in lamb, beef and pork meat: a review. Animal Feed Science and Technology, 113, 199-221.

SCOLLAN, N., HOCQUETTE, J.F., NUERNBERG, K., DANNENBERG, D., RICHARDSON, I. \& MOLONEY, I. (2006): Innovations in beef production systems that enchance the nutritional and health value of beef lipids and their relationship with meat quality. Meat Science, 74, $17-33$.

SIMOPOULOS A.P. (2002): The importance of the ratio of omega-6/omega-3 essential fatty acids. Biomedicine and Pharmacotherapy, 56, 365-379.

SRETENOVIĆ, L., PANTELIĆ, V., NOVAKOVIĆ, Ž., (2009): Importance of utilization of omega-3 fatty acids in human and animal nutrition. Biotechnology in Animal Husbandry, 25(5-6-1), pp. 439-449.

STATISTICA (Data Analysis Software System), v.8.0. Stat-Soft, Inc, USA (www. statsoft.com) (2006):

STEVANOVIĆ, J., PALIĆ, D., OKANOVIĆ, Đ. (2011): Legislation and risks of use of nutritional feed supplements. Food and Feed Research, 38(1), 21-26.

VERESBARANJI, I. (1996): In Karlović, Đ. \& Andrić, N. (Eds.) Kontrola kvaliteta semena uljarica (pp. 311-314). Tehnološki fakultet Novi Sad, Savezni zavod za standardizaciju, Beograd.

WOOD. J.D.. RICHARDSON. R.I.. NUTE. G.R.. FISHER. A.V.. CAMPO. M.M.. KASAPIDOU. E. SHEARD. P.R. \& ENSER. M. (2003): Effect of fatty acids on meat quality: A review. Meat Science. 66. 21 - 32.

WOOD, J.D., ENSER, M., FISHER, A.V., NUTE, G.R., SHEARD, P.R, RICHARDSON, R.I., HUGES, S.I. \& WHITTINGTON, F. M. (2008): Fat deposition, fatty acid composition and meat quality: A review. Meat Science, 78, $343-358$.

Received 17 May 2012; accepted for publication 5 July 2012 